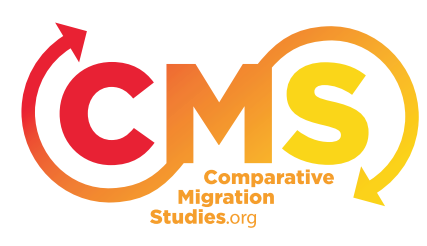

\title{
Solidarity and Trust in the Common European Asylum System
}

\author{
Valsamis Mitsilegas
}

CMS 2 (2): 181-202

DOI: $10.5117 / C M S 2014.2 . M I T S$

\begin{abstract}
The article examines the evolution of concepts of solidarity and trust in the Common European Asylum System by analysing the legislative and judicial development of the Dublin system of intra-EU transfers of asylum seekers. The article argues that concepts of solidarity and trust which focus exclusively on the needs and interests of EU Member States are inadequate to address the requirement for the EU to respect fully human rights, in particular after the entry into force of the Lisbon Treaty. The article puts forward a concept of solidarity based on the individual which would ensure the full respect of the rights of asylum seekers.
\end{abstract}

Keywords: European Union, migration, asylum, Common European Asylum System, Dublin, solidarity, trust, human rights

\section{Introduction}

The Lisbon Treaty has called for the development of a common European asylum policy, taking forward the first stage of European integration in the field achieved post-Amsterdam. Such common asylum policy is not synonymous however with a uniform asylum system across the EU marked by a single asylum procedure or a single refugee status across the Union. Rather, the determination of asylum applications continues to take place at the national level, with national procedures and national determination outcomes. The focus of this article will be to analyse how these national asylum systems interact under European Union law, following the criteria of allocation of state responsibility to examine asylum applications set out in the Dublin Regulation. The main features of the Dublin system will 
be explored, and its emphasis on automaticity in inter-state cooperation leading to the transfer of asylum seekers between Member States will be highlighted. Automaticity in inter-state cooperation on asylum poses fundamental questions both as regards the capacity of all EU Member States at any given time to apply the Dublin system and, more importantly, as regards the impact of automatic transfers to the fundamental rights of the affected asylum seekers. In order to address these questions, the article will focus from a legal perspective on two key concepts in the evolution of European asylum law: the concept of solidarity and the concept of trust. The conceptualisation of solidarity and trust by European Union institutions will be evaluated critically, with the focus being primarily on the recent seminal ruling of the Court of Justice of the European Union in the case of N.S. and its impact on the development of European asylum law. The article will then demonstrate the extent to which the Court's case-law has influenced the development of concepts of solidarity and trust in postLisbon secondary European asylum law, in particular with regard to the so-called Dublin III Regulation. The article will cast light on the evolution of the concepts of solidarity and trust in the legal order of the European Union, while highlighting the persistent limits in the protection of the fundamental rights of asylum seekers in the European Union which are exacerbated by national differences in protection. The article will put forward the need for a reconceptualization of solidarity and trust from the perspective of the asylum seeker and underpinned by an effective commitment to the protection of fundamental rights in the European Union.

\section{Inter-state cooperation as the basis of the Common European Asylum System - the system established by the first Dublin Regulation}

While a key element of the evolution of the European Union into an Area of Freedom, Security and Justice has been the abolition of internal borders between Member States and the creation thus of a single European area where freedom of movement is secured, this single area of movement has not been accompanied by a single area of law. This is certainly the case with European asylum law. Already in 1999, the European Council Tampere Conclusions stated that 'in the longer term, Community rules should lead to a common asylum procedure and a uniform status for those who are granted asylum throughout the Union.' (paragraph 15). However, 15 years after this statement, asylum applications in the EU are still examined by 
individual Member States following a national asylum procedure. The abolition of internal borders in the Area of Freedom, Security and Justice has thus not been followed by a unification of European asylum law. The focus has rather been on the gradual harmonisation of national asylum legislation with the entry into force of the Amsterdam Treaty leading to the adoption of a series of minimum standards in the field of asylum law, which led to the adoption of a series of Directives on minimum standards on refugee qualification ${ }^{1}$, asylum procedures ${ }^{2}$ and reception conditions for asylum seekers ${ }^{3}$. The Lisbon Treaty contains a legal basis enabling a higher level of harmonisation in European asylum law: Article 78(2) TFEU enables inter alia the adoption of measures for common asylum procedures and reception condition standards. A number of further harmonisation measures have been adopted by the EU legislator since the entry into force of the Treaty. ${ }^{4}$ These harmonisation measures have been accompanied by a cooperative system of intra-EU allocation of responsibility for the examination of asylum claims. Such a system had already been established in public international law shortly after the fall of the Berlin Wall by the 1990 Dublin Convention (Blake, 2001), which was replaced post-Amsterdam by the Dublin Regulation. ${ }^{5}$ Placed in the broader context of the construction of an Area of Freedom, Security and Justice, the Dublin Regulation has been designed to serve not only asylum policy, but also broader border and immigration control objectives. According to the Preamble to the Regulation, 'the progressive creation of an area without internal frontiers in which free movement of persons is guaranteed in accordance with the [then] Treaty establishing the European Community and the establishment of [the then] Community policies regarding the conditions of entry and stay of third country nationals, including common efforts towards the management of external borders, makes it necessary to strike a balance between responsibility criteria in a spirit of solidarity'( Preamble, recital 8. Emphasis added.).

The significance of border control considerations is evident in the formulation of the criteria established by the Regulation to allocate responsibility for the examination of asylum applications by Member States. The Regulation puts forward a hierarchy of criteria to determine responsibility (Chapter III of the Regulation, Articles 5-14). While on top of this hierarchical list one finds criteria such as the applicant being an unaccompanied minor (Article 6), family reunification considerations (Articles 7 and 8) or a legal relationship with an EU Member State (such as the possession of a valid residence document or a visa- Article 9), following these criteria one finds the criterion of irregular entry into the Union: if it is established that 
an asylum seeker has irregularly crossed the border into a Member State having come from a third country, this Member State will be responsible for examining the application for asylum (Article 10). Irregular entry thus triggers state responsibility to examine an asylum claim. The very occurrence of the criteria set out in the Dublin Regulation sets out a system of automatic inter-state cooperation which has been characterised as a system of negative mutual recognition (Guild, 2004). Recognition can be viewed as negative here in that the occurrence of one of the Dublin criteria creates a duty for one Member State to take charge of an asylum seeker and thus recognise the refusal of another Member State (which transfers the asylum seeker in question) to examine the asylum claim. The Dublin Regulation thus introduces a high degree of automaticity in inter-state cooperation. Member States are obliged to take charge of asylum seekers if the Dublin criteria are established to apply, with the only exceptions to this rule (on the basis of the so-called sovereignty clause in Article 3(2) and the humanitarian clause in Article 15 of the Regulation) being dependant on the action of the Member State which has requested the transfer. As in the case of mutual recognition in criminal matters (Mitsilegas, 2006), automaticity in inter-state cooperation is accompanied with the requirement of speed, which is in this case justified on the need to guarantee effective access to the asylum procedure and the rapid processing of asylum applications (Article 17(1) and Preamble, recital 4).

Notwithstanding the claim of the Dublin Regulation that one of its objectives is to facilitate the processing of asylum applications, it is clear that the Regulation has been drafted primarily with the interests of the state, and not of the asylum seeker, in mind. The Regulation establishes a mechanism of automatic inter-state cooperation aiming to link allocation of responsibility for asylum applications with border controls and in reality to shift responsibility for the examination of asylum claims to Member States situated at the EU external border. The specificity of the position of individual affected asylum seekers is addressed by the Regulation only marginally, with the Regulation containing limited provisions on remedies: a non-suspensive remedy to the asylum seeker with regard to the decision not to examine his or her application (Article 19(2)) and the decision concerning his or her taking back by the Member State responsible to examine the application (Article 2o(1)(e)). The asylum determination system envisaged by the Dublin Regulation has been a system aiming at speed. This objective has recently been confirmed by the Court of Justice which in the case of Abdullahi (Case C-394/12, judgment of 10 December 2013), stated that one of the principal objectives of the Dublin Regulation is the 
establishment of a clear and workable method for determining rapidly the Member State responsible for the processing of an asylum application so as to guarantee effective access to the procedures for determining refugee status and not to compromise the objective of the rapid processing of asylum claims (paragraph 59). Privileging the interests of the state in relation to the position of the asylum seeker is linked to the perception that the abolition of internal borders in the Area of Freedom, Security and Justice will lead to the abuse of domestic systems by third-country nationals. The terminology of abuse can be found in cases before the Court of Justice of the European Union, with Advocate General Trstenjak recently stating that the purpose of the hierarchy of criteria in the Dublin Regulation is first to determine responsibility on the basis of objective criteria and to take into account of the objective of preserving the family and secondly to prevent abuse in the form of multiple simultaneous or consecutive applications for asylum (Case C-245/11, $K$, Opinion of 27 June 2012, paragraph 26, emphasis added). In the political discourse, this logic of abuse has been encapsulated in the terminology of 'asylum shopping'. Giving evidence before the House of Lords European Union Committee on the draft Dublin Regulation, the then Home Office Minister Angela Eagle stated that the underlying objectives of the Regulation were 'to avoid asylum shopping by individuals making multiple claims in different Member States and to address the problem known as 'refugees in orbit'... it is in everybody's interests to work together to deal with some of the issues of illegal migration and to get some coherence into the asylum seeking issue across the European Union'(House of Lords 2001-2002 paragraph 27). Under this logic of abuse, the Regulation aims largely to automatically remove the unwanted, third-country nationals who are perceived as threats to the societies of the host Member States. The legitimate objective of applying for asylum is thus securitised in the law of the European Union.

\section{Solidarity in the Common European Asylum System}

As seen above, the basis of the Common European Asylum System remains the determination of asylum claims at the national level. Central to this system, the Dublin Regulation aims at allocating state responsibility for the examination of asylum applications and involves thus the regulation of the interplay between national asylum systems. The operation of the Dublin Regulation has raised a number of questions involving fairness and solidarity in the allocation of such responsibility. While the Preamble 
to the Dublin Regulation stresses the need to 'strike a balance between responsibility criteria in a spirit of solidarity' (Preamble, recital 8) key criticisms as regards the system established by the Regulation have been that it disregards the particular migratory pressure that certain EU Member States situated on the EU external border are facing, and that it results into these Member States being allocated a disproportionate number of asylum applicants compared with other Member States. In its 2007 Green Paper on the future Common European Asylum System, the European Commission accepted that the Dublin system 'may de facto result in additional burdens on Member States that have limited reception and absorption capacities and that find themselves under particular migratory pressures because of their geographical location '(European Commission, 2007:10, emphasis added). The impact of increased migratory pressures on national systems has also been highlighted with regard to Greece by the Court of Justice in its ruling in N.S., where the Court noted that the parties who have submitted observations to the Court were in agreement that 'that Member State was, in 2010, the point of entry in the European Union if almost $90 \%$ of illegal immigrants, that influx resulting in a disproportionate burden being borne by it compared to other Member States and the inability to cope with the situation in practice.' (Joined Cases C-411/10 and C-493/10, N. S. and M. E., judgment of 21 December 2011, paragraph 9o, emphasis added). What is common to both passages is that they focus on the impact of migration flows on the state, rather than on the asylum seeker, and that they use the term 'burden' to describe increased pressures upon the state- with asylum seekers thus viewed implicitly as a burden to national systems. Solidarity here thus takes the form of what has been deemed and analysed as 'burden sharing' (Betts 2003; Boswell 2003; Noll 2003; Thielemann, 2003 a and b) and in particular from a legal perspective the sharing of the responsibility for increased flows of asylum seekers. As with the logic of abuse underpinning the Dublin system, the logic of burden sharing in effect securitises asylum flows by viewing asylum seekers and asylum seeking in a negative light (Noll, 2003). As it has been eloquently noted, asylum has historically been seen as ripe for burden sharing because the reception and protection of internally displaced persons is widely seen as a burden on receiving countries which can occur unexpectedly and on a large scale (European Parliament, 2011).

The conceptualisation of asylum flows from a burden sharing perspective promotes a concept of solidarity which is state-centered, securitised and exclusionary. Solidarity is state-centered in that it places emphasis on the interests of the state and not on the position of the asylum seeker. This 
emphasis on the interests of the state is confirmed by the provisions of the Lisbon Treaty on solidarity in the Area of Freedom, Security and Justice. According to Article 67(2) TFEU, the Union shall ensure the absence of internal border controls for persons and shall frame a common policy on asylum, immigration and external border control, based on solidarity between Member States, which is fair towards third-country nationals. Article 80 TFEU further states that the policies of the Union on borders, asylum and immigration will be governed by the principle of solidarity and fair sharing of responsibility, including its financial implications, between the Member States. Solidarity is thus premised upon inter-state cooperation in a system which arguably reflects the broader principle of loyal cooperation under EU law (McDonough and Tsourdi, 2012a). Solidarity is also securitised: as with other areas of European Union law, solidarity in European asylum law reflects a crisis mentality (Borgmann-Prebil and Ross, 2010) and has led to the concept being used with the aim of alleviating perceived urgent pressures on Member States. This view of solidarity as an emergency management tool is found elsewhere in the Treaty, in the solidarity clause established in Article 222 TFEU according to which the Union and its Member States shall act jointly in a spirit of solidarity if a Member State is the object of a terrorist attack or the victim of a natural man-made disaster. The concept of solidarity here echoes the political construction of solidarity in European asylum law, in responding to perceived urgent threats. It is a framed in a way of protecting the state and requires cooperation not between the state and the individual but between the state and the European Union. State-centered securitised solidarity in the field of asylum echoes Ross's assertion that the political power of security can attempt to appropriate solidarity for its own ends (Ross, 2010:39).

Placed within a state-centric and securitised framework, solidarity is also exclusionary. The way in which the concept of solidarity has been theorised in EU law leaves little, if any space for the application of the principle of solidarity beyond EU citizens or those 'within' the EU and its extension to third-country nationals or those on the outside. In a recent thought-provoking analysis on solidarity in EU law, Sangiovanni argues for the development of principles on national solidarity (which define obligations among citizens and residents of member states), principles of member state solidarity (which define obligations among member states) and principles of transnational solidarity (which define obligations among EU citizens as such) (Sangiovanni, 2013:217). Third-country nationals are notably absent from this model of solidarity. This exclusionary approach to solidarity appears to be confirmed by the Treaties, with the Preamble 
to the Treaty on the European Union expressing the desire of the signatory states 'to deepen the solidarity between their peoples while respecting their history, their culture and their traditions' (Preamble, recital 6, emphasis added). Solidarity functions thus as a key principle of European identity which is addressed to EU Member States and their 'peoples' (see also Article 167 TFEU on Culture), but the extent to which such European identity based on solidarity also encompasses third-country nationals is far from clear (Mitsilegas, 1998). Although asylum law is centered on assessing the protection needs of third-country nationals, and in this capacity they must constitute the primary 'recipients' of solidarity in European asylum law, the application of the principle of solidarity in this field appears thus to follow the exclusionary paradigm of solidarity in other fields of EU law where issues of distributive justice arise prominently. Writing on the position of irregular migrants EU social welfare law, Bell has eloquently noted that third-country nationals lack the ties of shared citizenship, whilst the extension of social and economic entitlements to them cannot easily be based on a reciprocal view of solidarity (Bell, 2010:151). Asylum seekers seem to be included in a continuum of exclusionary solidarity in this context.

The approach to solidarity based primarily upon the interests of the state and those deemed to be on the inside is further reflected in the Conclusions of the Justice and Home Affairs Council 'on a Common Framework for genuine and practical solidarity towards Member States facing particular pressures on their asylum systems, including through mixed migration flows' ${ }^{6}$ The Conclusions confirm the use of national asylum systems as an element of migration management in the European Union (paragraph 8ii) and put forward a multi-faceted concept of solidarity. At the heart of the Council's approach is a concept of solidarity based on security, emergency and prevention. This takes the form of solidarity through the establishment of a mechanism for early warning, preparedness and crisis Management within the Dublin System (paragraphs 9-10) with an emphasis on detecting situations likely to give rise to particular pressures in advance (paragraph 10). Beyond Dublin, the Conclusions focus on solidarity through preventive cooperation,(paragraph 12) including the acceleration of negotiations for the establishment of a European Border Surveillance System (EUROSUR- paragraph 12v), and place great emphasis on solidarity in emergency situations (paragraph 13). The focus here is thus not only to support Member States in dealing with asylum seekers within the European Union, but also to prevent the entry of asylum seekers to the Union in the first place (Mitsilegas 2012a). This preventative vision of solidarity is inextricably linked with two parallel visions on solidarity reflected in the Council conclusions: solidarity based 
on delegation, and solidarity based on externalisation. As regards solidarity based on delegation, it is noteworthy that the Council envisages the implementation of solidarity to take place by the operational action of EU agencies such as the European Asylum Support Office $(\mathrm{EASO})^{7}$ and the European Borders Agency (FRONTEX) ${ }^{8}$ and EU databases such as EUROSUR. ${ }^{9}$. The establishment of EASO is also inextricably linked with the Commission's vision of solidarity in European asylum law (European Commission, 2011). The role of FRONTEX is envisaged by the Council as particularly important in implementing solidarity in emergency situations, with seven out of the thirteen proposed actions referring specifically to the agency and with the agency having a strong preventive and broader migration management role. FRONTEX should in particular'provide assistance through the coordination of Member States' actions and efforts for control and surveillance of external borders, including continuous monitoring with consultation of Member States concerned and thorough risk analysis of emerging and present threats from illegal immigration and propose appropriate measures to tackle identified threats.' (point 13v). The use of enforcement mechanisms such as FRONTEX and EUROSUR in this context is another example of the securitisation of asylum in the European Union. Reliance on agencies and databases in this context may create gaps in legal responsibility and accountability and may serve to depoliticise state action in the field of migration and asylum (Mitsilegas 2012a). Similar concerns arise from the emphasis on solidarity based on externalisation. Externalisation here takes place in particular via cooperation between the EU and its Member States on the one hand and third countries on the other (paragraph 20) (but also FRONTEX and third countries (paragraph 13ix) with the aim of preventing asylum flows into the EU.

A further impetus for the reform of the Common European Asylum System has been created by the Lisbon Treaty itself. Article 80 TFEU introduces the principle of solidarity and fair sharing of responsibility with regard to EU border, immigration and asylum policies and their implementation and states that whenever necessary, Union law in the field shall contain appropriate measures to give effect to this principle. As it has been noted, the principle of solidarity in Article 8o TFEU can act as an interpretative guide for the Court of Justice (Ross 2010), in particular when dealing with questions related to European asylum law (McDonough and Tsourdi 2012b). In interpreting European asylum law in the light of solidarity, the Court will have to introduce a paradigm change: it will have to depart from a state-centered, securitised and exclusionary concept of solidarity and underpin the principle of solidarity with the obligation of the EU and its 
Member States to respect fundamental rights- in this manner, the principle of solidarity will be removed from its current exclusive focus on the state (and inter-state solidarity) and will also focus on solidarity towards the affected individuals. The Court has already demonstrated such tendencies in its ruling in N.S., where it linked the principle of solidarity with the need for Member States due to order a transfer under the Dublin Regulation to assess the functioning of the asylum system in the responsible Member State and evaluate the fundamental rights risks for the affected individual if a transfer takes place (paragraph 91). While solidarity is undoubtedly valuable as an interpretative tool in this context, it is submitted that Article 80 TFEU can also be used in conjunction with the asylum provisions in the Treaty (Article $78 \mathrm{TFEU}$ ) as a legal basis for the adoption of measures leading gradually to the establishment of a single European Union asylum system.

\section{Trust in the Common European Asylum System - the impact of N.S.}

As mentioned above, the system of inter-state cooperation established by the Dublin Regulation is based on a system of negative mutual recognition. Mutual recognition creates extraterritoriality (Nicolaidis, 2007) and presupposes mutual trust (Mitsilegas, 2006): in a borderless Area of Freedom, Security and Justice, mutual recognition is designed so that the decision of an authority in one Member State can be enforced beyond its territorial legal borders and across this area speedily and with a minimum of formality. As in EU criminal law, in the field of EU asylum law automaticity in the transfer of asylum seekers from one Member State to another is thus justified on the basis of a high level of mutual trust. This high level of mutual trust between the authorities which take part in the system is premised upon the presumption that fundamental rights are respected fully by all EU Member States across the European Union (Mitsilegas, 2009). In asylum law, as evidenced in the Preamble of the Dublin Regulation, such mutual trust is based additionally upon the presumption that all EU Member States respect the principle of non-refoulement and can thus be considered as safe countries for third-country nationals. (Preamble, recital 2). In its extreme, this logic of mutual recognition premised upon mutual trust absolves Member States from the requirement to examine the individual situation of asylum applicants and disregards the fact that fundamental rights and international and European refugee law may not be fully respected at all time in all cases in EU Member States, especially in the light of the increased 
pressure certain EU Member States are facing because of the emphasis on irregular entry as a criterion for allocating responsibility under the Dublin Regulation. Inter-state cooperation resulting to the transfer of asylum seekers from EU Member State to EU Member State thus occurs almost automatically, without many human rights questions being asked by the authorities examining requests for Dublin transfers.

This system of inter-state cooperation based on automaticity and trust in the field of European asylum law was challenged in Luxembourg in the joint cases of N.S. and M.E mentioned earlier in the article (N.S.) The Court of Justice was asked to rule on two references for preliminary rulings by the English Court of Appeal and the Irish High Court respectively. The referring courts asked for guidance on the extent to which the authority asked to transfer an asylum seeker to another Member State is under a duty to examine the compatibility of such transfer with fundamental rights and, in the affirmative, whether a finding of incompatibility triggers the 'sovereignty clause' in Article 3(2) of the Dublin Regulation. In a seminal ruling, the Court found that an application of the Dublin Regulation on the basis of the conclusive presumption that the asylum seeker's fundamental rights will be observed in the Member State primarily responsible for his application is incompatible with the duty of the Member States to interpret and apply the Regulation in a manner consistent with fundamental rights (paragraph 99). Were the Regulation to require a conclusive presumption of compliance with fundamental rights, it could itself be regarded as undermining the safeguards which are intended to ensure compliance with fundamental rights by the European Union and its Member States (paragraph 100). Most importantly, such presumption is rebuttable (paragraph 104). If it is ascertained that a Dublin transfer will lead to the breach of fundamental rights as set out in the judgment, Member States must continue to apply the criteria of Article 13 of the Dublin Regulation. (paragraphs 95-97). The Member State in which the asylum seeker is present must, however, ensure that it does not worsen a situation where the fundamental rights of that applicant have been infringed by using a procedure for determining the Member State responsible which takes an unreasonable length of time. If necessary, that Member State must itself examine the application in accordance with the procedure laid down in the sovereignty clause set out in Article 3(2) of the Regulation (paragraph 98). N.S. followed the ruling of the European Court of Human Rights in the case of M.S.S. (M.S.S. v. Belgium and Greece, judgment of 21 January 2011, Application No 30696/o9). In M.S.S., the Strasbourg Court found Dublin transfers from Belgium to Greece incompatible with the Convention and importantly found both 
the sending and the receiving states in breach of the Convention in this context (Moreno-Lax, 2012).M.S.S., which has also proven to be influential on subsequent Strasbourg case-law on onward transfers to third countries (Hirsi Jamaa, Application no. 27765/og, concerning the transfer of asylum seekers from Italy to Libya) has contributed to the Court of Justice in opposing the automaticity in the operation of the Dublin Regulation by not accepting the non-rebuttable assumption of compatibility of EU Member States action with fundamental rights.

The Court's rejection of the conclusive presumption that Member States will respect the fundamental rights of asylum seekers has admittedly been accompanied by the establishment by the Court of Justice of a high threshold of incompatibility with fundamental rights: a transfer under the Dublin Regulation would be incompatible with fundamental rights if there are substantial grounds for believing that there are systemic flaws in the asylum procedure and reception conditions for asylum applicants in the Member State responsible, resulting in inhuman or degrading treatment, within the meaning of Article 4 of the Charter (on the prohibition of torture and inhuman or degrading treatment or punishment), of asylum seekers transferred to the territory of that Member State (paragraph 85). Member States, including the national courts, may not transfer an asylum seeker to the Member State responsible within the meaning of the Regulation where they cannot be unaware that systemic deficiencies in the asylum procedure and in the reception conditions of asylum seekers in that Member State amount to substantial grounds for believing that the asylum seeker would face a real risk of being subjected to inhuman or degrading treatment within the meaning of Article 4 of the Charter (paragraph 94). This high threshold is justified on the basis of the assumption that all Member States respect fundamental rights and by the acceptance of the existence, in principle, of mutual trust between Member States in the context of the operation of the Dublin Regulation. According to the Court, it is precisely because of that principle of mutual confidence that the European Union legislature adopted the Dublin Regulation in order to rationalise the treatment of asylum claims and to avoid blockages in the system as a result of the obligation on State authorities to examine multiple claims by the same applicant, and in order to increase legal certainty with regard to the determination of the State responsible for examining the asylum claim and thus to avoid forum shopping, it being the principal objective of all these measures to speed up the handling of claims in the interests both of asylum seekers and the participating Member States (paragraph 78). It cannot be concluded that any infringement of a fundamental right will affect compliance with the 
Dublin Regulation, (paragraph 81) as at issue here is the raison d'etre of the European Union and the creation of an area of freedom, security and justice and, in particular, the Common European Asylum System, based on mutual confidence and a presumption of compliance by other Member States with EU law and in particular fundamental rights (paragraph 83). The Court found that it would not be compatible with the aims of the Dublin Regulation were the slightest infringement of other measures in the Common European Asylum System to be sufficient to prevent the transfer of an asylum seeker to the Member State primarily responsible under the Dublin Regulation (paragraph 84) and reiterated the objectives of the Dublin Regulation to establish a clear and effective method for dealing with asylum applications by allocating responsibility speedily and based on objective criteria (paragraph 854 and 855; Mitsilegas 2012b).

N.S. constitutes a significant constitutional moment in European Union law and introduces a fundamental change in the development of inter-state cooperation in European asylum law. The rejection by the Court of the conclusive presumption of fundamental rights compliance by EU Member States signifies the end of automaticity in inter-state cooperation. The end of automaticity operates on two levels. Firstly, national authorities (in particular courts) which are asked to execute a request for a transfer under the Dublin Regulation are now under a duty to examine, on a case-by-case basis, the individual circumstances in each case and the human rights implications of a transfer in each particular case. Automatic transfer of individuals is no longer allowed under EU law. Secondly, national authorities are obliged to refuse to execute such requests when the transfer of the affected individuals will result in the breach of their fundamental rights within the terms of N.S. The ruling in N.S. has thus introduced a fundamental rights mandatory ground for refusal to transfer an asylum seeker in the system established by the Dublin Regulation (Mitsilegas, 2012b). While the Court of Justice in N.S. placed limits to the automaticity in the operation of the Dublin Regulation, it was careful not to condemn the Dublin system as a whole. The requirement for Member States to apply the Regulation in compliance with fundamental rights did not lead to a questioning of the principle behind the system of allocation of responsibility for asylum applications between Member States. There are three main limitations to the Court's reasoning: Firstly, the Court used the discourse of the presumption of the existence of mutual trust between Member States, although this discourse has been used thus far primarily in the context of cooperation in criminal matters (Mitsilegas, 2006, 2009) and not in the field of asylum law, where the Dublin Regulation has co-existed with a 
number of EU instruments granting rights to asylum seekers (Labayle, 2011). Secondly, a careful reading of N.S. also demonstrates a nuanced approach to the sovereignty clause in Article 3(2) of the Regulation: the Court stressed that, prior to Member States assuming responsibility under 3(2), they should examine whether the other hierarchical criteria set out in the Regulation apply. Thirdly, it should be reminded again that the threshold set out by the Court for disapplying the system is high: mere non-implementation of EU asylum law is not sufficient to trigger non-return, systemic deficiencies in the national asylum systems must occur leading to a real risk of breach of fundamental rights (Mitsilegas, 2012b).

In addition to its contribution to questioning automaticity in the Dublin system, the Court's ruling in N.S. is important in highlighting that the adoption of legislative measures conferring rights to asylum seekers may not be on its own adequate to ensure the effective protection of fundamental rights in the asylum process. N.S. has demonstrated that the existence of EU minimum harmonisation on rights may not prevent systemic deficiencies in the protection of fundamental rights in Member States. Monitoring and extensive evaluation of Member States' implementation of European asylum law and their compliance with fundamental rights is essential in this context. In addition to the standard constitutional avenues of monitoring compliance with EU law at the disposal of the European Commission as guardian of the treaties, the Lisbon Treaty includes an additional legal basis for the adoption of measures laying down the arrangements whereby Member States, in collaboration with the European Commission, conduct objective and impartial evaluation of the Union policies in the field of the Area of Freedom, Security and Justice, in particular in order to facilitate full application of the principle of mutual recognition. (Article 70 TFEU). The Justice and Home Affairs Council has called recently for the establishment of evaluation mechanisms in the field of EU asylum law. ${ }^{10}$ On the basis of the findings of European courts in M.S.S. and N.S., the work of organisations such as the UNHCR and civil society actors must be central in the processes of monitoring the situation of international protection on the ground in EU Member States. However, the question of the value of the findings of civil society organisations and the UNHCR as evidence before national and European authorities remains open. While both the Luxembourg and the Strasbourg Courts have referred to the work of UNHCR in their rulings, the Court of Justice found in a recent ruling ( Case C-528/11, judgment of 30 May 2013, Halafv Darzhavna agentsia za bezhantiste pri Ministerskia savet) that the Member State in which the asylum seeker is present is not obliged, during the process of determining the Member State responsible, 
to request the UNHCR to present its views where it is apparent from the documents of that Office that the Member State indicated as responsible by the criteria in Chapter III of the Dublin Regulation is in breach of the rules of European Union law on asylum. However, work done by civil society and UNHCR, the transparency their presence creates and the information produced and its use by national and European authorities, including courts, is key in shifting the focus of solidarity towards the asylim seeker and in contributing towards the establishment of evidence-based trust in the Common European Asylum System.

\section{Solidarity and Trust After Dublin III}

Following the Court's ruling in N.S., the revision of the Dublin Regulation post-Lisbon has been eagerly awaited. The adoption of the new instrument (the so-called 'Dublin III' Regulation) ${ }^{11}$ may come as a disappointment to those expecting a radical overhaul of the Dublin system. The Regulation maintains intact the system of allocation of responsibility for the examination of asylum applications by EU Member States under the same list of hierarchically enumerated criteria set out in its pre-Lisbon predecessor (see Chapter III of the Regulation, Articles 7-15). However, the Dublin III Regulation has introduced an important systemic innovation to take into account the Court's ruling in N.S.: according to Article 3(2) of the Regulation, second and third indent,

'Where it is impossible to transfer an applicant to the Member State primarily designated as responsible because there are substantial grounds for believing that there are systemic flaws in the asylum procedure and in the reception conditions for applicants in the Member State, resulting in a risk of inhuman or degrading treatment within the meaning of Article 4 of the Charter of Fundamental Rights of the European Union, the determining Member State shall continue to examine the criteria set out in Chapter III in order to establish whether another Member State can be designed as responsible.

Where the transfer cannot be made pursuant to this paragraph to any Member State designated on the basis of the criteria set out in Chapter III or to the first Member State with which the application was lodged, the determining Member State shall become the Member State responsible.'

The European legislator has thus attempted to translate the Court's ruling in N.S. to establish an exception to the Dublin system. The high threshold adopted by the Court in the specific case has been adopted in 
Dublin III, with the transfer of an asylum applicant beign impossible when there are substantial grounds to believe that there are systemic flaws in the asylum system of the receiving Member State which will result in a risk of specifically inhuman and degrading treatment (and not necessarily as regards the risk of the breach of other fundamental rights). Even when such risk has been established, responsibility does not automatically fall with the determining Member State, which only becomes responsible if no other Dublin criterion enabling the transfer of the applicant to another Member State applies. While it could be argued that the new Dublin Regulation could require expressly a higher level of protection of human rights when designing the Dublin system, the legislative recognition of the N.S. principles is important in recognising the end of the automaticity in Dublin transfers and placing national authorities effectively under the obligation to examine the substance of the applicants' relevant human rights claims prior to authorising a transfer. Article $3(2)$ places thus an end to the automatic presumption of human rights compliance by EU Member States and reconfigures the relationship of mutual trust between national executives.

A greater emphasis on the rights of the asylum seeker is also evident in other, specific, provisions of the new Regulation. The provisions on remedies have been strengthened, in particualr as regards their suspensive effect (Article $27(3)$. The rights of minors and family members are highlighted, with the Regulation containing strong provisions on evidence in determining the Dublin criteria (Article 7(3)) and in emphasising the possibility of Member States to make use of the discretionary provision which enables them to assume the examination of an asylum claim (the former 'sovereignty clause in Article 3(2) which has morphed into a 'discretionary clause' in Article 17), in particular when this concerns family reunification (Article 17(2)). The emphasis on the protection of the rights of family reunification and of minors has also been evident in the case-law of the Court of Justice in relation to the pre-Lisbon Dublin Regulation. In a case involving unaccompanied minors, the Court has held that since unaccompanied minors form a category of particularly vulnerable persons, it is important not to prolong more than it is strictly necessary the procedure for determining the Member State responsible which means that, as a rule, unaccompanied minors should not be transferred to another Member State (Case C-648/11, $M A, B T$ and DA $v$ Secretary of State for the Home Department, judgment of 6 June 2013, paragraph 55). The Court has also extended the scope of the Dublin criterion of examination of a family asylum application on humanitarian grounds, giving a broad meaning to the humanitarian provisions of 
the Regulation (Case C-245/11, Kv Bunesasylamt, judgment of 6 November 2012). The interpretation of humanitarian, human rights and family reunification clauses in an extensively protective manner by the Court signifies another inroad to the automaticity in inter-state cooperation which the Dublin system aims to promote and reiterates the required emphasis on the examination of the substance of individual claims.

A substantive innovation introduced by Dublin III involves the translation of a version of the principle of solidarity into legal terms. Article 33 of the Regulation introduces a so-called mechanism for early warning, preparedness and crisis management. Where the Commission establishes that the application of the Dublin Regulation may be jeopardised due either to a substantiated risk of particular pressure being placed on a Member States' asylum system and/or to problems in the functioning of the asylum system of a Member State, it shall, in cooperation with EASO, make recommendations to that Member State, inviting it to draw up a preventive action plan. Member States are not obliged to act upon these recommendations but they must inform the Council and the Commission whether it intends to present a preventive action plan in order to overcome these problems (Article 33(1)). However, if Member States decide to draw up such a plan, they must submit it and regularly report to the Council and the Commission (Article 33(2)). The system provides for an escalation process: where the Commission establishes, on the basis of EASO's analysis, that the implementation of the preventive action plan has not remedied the deficiencies identified or where there is a serious risk that the asylum situation in the Member State concerned develops into a crisis which is unlikely to be remedied by a preventive action plan, the Commission, in cooperation with the EASO as applicable, may request the Member State concerned to draw up a crisis management action plan. Member States must do so promptly, and at the latest within three months of the request (Article 33(3)). Throughout the entire process for early warning, preparedness and crisis management established in this Article, the Council will closely monitor the situation and may request further information and provide political guidance, in particular as regards the urgency and severity of the situation and thus the need for a Member State to draw up either a preventive action plan or, if necessary, a crisis management action plan. The European Parliament and the Council may, throughout the entire process, discuss and provide guidance on any solidarity measures as they deem appropriate (Article 33(4)). The early warning mechanism established by the Dublin III Regulation is considerably weaker than an earlier Commission version whereby this mechanism would be accompanied by an emergency 
mechanism which would allow the temporary suspension of transfers of asylum seekers to Member States facing disproportionate pressure to their asylum systems, which has not been accepted by Member States, ${ }^{12}$ presumably on sovereignty grounds. The outcome has been a mechanism which again views the asylum process largely from the perspective of the state and not of the affected individuals. The Preamble to Dublin III confirms this view by stating that an early warning process should be established in order to ensure robust cooperation within the framework of this Regulation and to develop mutual trust among Member States with respect to asylum policy. It is further claimed that solidarity, which is a pivotal element in the Common European Asylum System, goes hand in hand with mutual trust and that early warning will enhance trust (Preamble, recital 22). Solidarity and trust are viewed in reality from a traditional 'burden-sharing' perspective involving negotiation of support by the Union to affected Member States (and with the European Asylum Support Office emerging as a key player). Notwithstanding the case-law of the European courts and the findings of UNHCR and civil society, the position of the asylum seeker appears to still be considered as an afterthought.

\section{Conclusion}

The above analysis has demonstrated the limits of the concepts of solidarity and trust in European asylum law when viewed primarily as concepts serving exclusively the interests of Member States and not as concepts based upon the obligations of the European Union and its Member States to respect the fundamental rights of asylum seekers. The case-law of both the Strasbourg and the Luxembourg Courts has exposed the flaws inherent in the Dublin system of inter-state cooperation based upon automaticity and blind mutual trust between national authorities. N.S. has introduced the obligation to authorities asked to order a Dublin transfer to examine the fundamental rights implications of such transfer on a case-by-case basis and to refuse to execute a transfer when the latter will result to a breach of fundamental rights as a minimum under the terms described by the Court of Justice. European courts have provided an impetus towards greater scrutiny and evaluation of national asylum systems on the ground, leading to a proliferation and qualitative change of evaluation and monitoring mechanisms at EU level, but also at paying greater attention to evaluation reports by UNHCR and NGOs in the field. The requirement to monitor national asylum systems on the ground also informs the articulation of the 
concept of solidarity, with solidarity being increasingly viewed from the perspective of the affected asylum seeker. European asylum law adopted post-Lisbon has made only modest steps in addressing the human rights concerns arising from automaticity in the allocation of responsibility to examine asylum claims in Europe. However, the Court of Justice in a number of follow-up rulings interpreting the Dublin system has begun rebalancing the system towards the direction of the individual and has introduced inroads to the automaticity of the system on humanitarian, human rights and family reunification grounds. Developing the concepts of solidarity and trust from the perspective of the asylum seeker and not primarily of the state will be key to the evolution of the next stages of the Common European Asylum System. There is plenty of room for improvement to the system for the examination of asylum claims currently in place in the EU. Although references are made to a Common European Asylum System, such a system will remain fragmented if the emphasis remains primarily on the interests of the state and not on the affected individuals and if discrepancies remain between national asylum systems. A way forward for a true common system may be the move to a single system of asylum determination and refugee allocation within the EU. The European Commission has considered in a recent Green Paper the joint processing of asylum applications as a way forward ${ }^{13}$ and the Justice and Home Affairs Council called for both the examination of the possibility of the voluntary relocation of beneficiaries of international protection within the $\mathrm{EU}^{14}$ and for a study on the feasibility of joint processing of asylum claims within the EU. ${ }^{15}$ In the present European asylum system based on the functioning of national systems, rethinking solidarity from the perspective of the asylum seeker becomes imperative for European asylum law to comply with European constitutional and human rights law.

\section{Notes}

1. Council Directive 2004/83/EC on minimum standards for the qualification and status of third country nationals or stateless persons as refugees or as persons who otherwise need international protection and the content of the protection granted (OJ L304/12, 30.9.2004);

2. Council Directive $2005 / 85 /$ EC on minimum standards on procedures in Member States for granting or withdrawing refugee status (OJ L326/13, 13.12.2005).

3. Council Directive 2003/9/EC laying down minimum standards for the reception of asylum seekers, OJ L31/18, 6.2.2003.

4. The second stage asylum Directives entailing a higher level of harmonisation include: the reception conditions Directive (Directive 2013/33/EU, OJ L18o, 29/06/2013, p. 96; the procedures Directive (Directive 2013/32/EU, OJ L18o, 29/o6/2013, p. 6o); and the refugee qua- 
lification Directive (Directive 2011/95, OJ L337, 20/12/2011, p. 9). These Directives have been accompanied by the Regulation establishing a European Asylum Support Office (EASO) (Regulation No 349, OJ L132, 29.05.2010, p. 11) and by the revised EURODAC Regulation (Regulation No 603, OJ L180, 29/06/2013, p. 1).

5. Regulation $343 / 2003$ establishing the criteria and mechanisms for determining the Member State responsible for examining an asylum application lodged in one of the Member States by a third-country national, OJ L5o/1, 25.2.2003.

6. $315^{\text {st }}$ Justice and Home Affairs Council meeting, Brussels, 8 March 2012.

7. Regulation establishing a European Asylum Support Office (EASO) (Regulation No 349, OJ L132, 29.05.2010, p. 11 .

8. Council Regulation 2007/2004 establishing a European Agency for the Management of Operational Cooperation at the External Borders of the Member States of the European Union, OJ [2004] L349/1, amended by Regulation 863/2007 establishing a mechanism for the creation of Rapid Border Intervention Teams - OJ [2007] L199/3o.

9. Regulation (EU) No 1052/2013 establishing the European Border Surveillance System (EUROSUR), OJ L295, 6 November 2013, p. 11.

10. The Justice and Home Affairs Council of 22 September 2011 on the Common European Asylum System endorsed an asylum evaluation mechanism which would inter alia contribute to the development of mutual trust among Member States with respect to asylum policy- Council doc. $14464 / 11$, p. 8.

11. Regulation (EU) No 604/2013 of the European Parliament and of the Council of 26 June 2013 establishing the criteria and mechanisms for determining the Member State responsible for examining the application for international protection lodged in one of the Member States by a third-country national or a stateless person (recast), OJ L180/31, 29.6.2013.

12. Conclusions of the Justice and Home Affairs Council of 22 September 2011, Council document 14464/11, p. 8.

13. Paragraph $3 \cdot 3$.

14. Paragraph 16.

15. Paragraph 18.

\section{References}

Bell, M. (2010). Irregular Migrants: Beyond the Limits of Solidarity? in Ross M. \& Borgmann-Prebil Y. (eds.) Promoting Solidarity in the European Union. Oxford University Press, pp. 151-165.

Betts, A. (2003). Public Goods Theory and the Provision of Refugee Protection: The Role of the Joint-Product Model in Burden-Sharing Theory. Journal of Refugee Studies, 16:274-296.

Blake, N. (2001). The Dublin Convention and Rights of Asylum Seekers in the European Union in Guild E. \& Harlow C. (eds.) Implementing Amsterdam. Hart Publishing, pp. 95-115.

Borgmann-Prebil Y. \& Ross M. (2010). Promoting European Solidarity: Between Rhetoric or Reality? in Ross M. \& Borgmann-Prebil Y. (eds.) Promoting Solidarity in the European Union. Oxford University Press, $p p$. 1-22

Boswell, C. (2003). Burden-Sharing in the European Union. Lessons from the German and the UK Experience. Journal of Refugee Studies, 16:316-335.

European Commission (2011). Communication on Enhanced Intra-EU Solidarity in the Field of Asylum. An EU Agenda for Better Responsibility-Sharing and More Mutual Trust. COM (2011) 835 final, Brussels, 2.12.2011.

European Commission (2007). Green Paper on the future Common European Asylum System. COM (2007) 301 final, Brussels, 6.6.3007 
European Parliament, Directorate-General for Internal Policies (2011). The Implementation of Article 80 TFEU on the Principle of Solidarity and Fair Sharing of Responsibility, including its Financial Implications, between Member States in the Field of Border Checks, Asylum and Immigration (authors: D. Vanheule, J. van Selm, Ch. Boswell on behalf of Eurasylum).

Guild, E. (2004). Seeking Asylum: Storm Clouds between International Commitments and EU Legislative Measures. European Law Review, 29, 198-218.

House of Lords Select Committee on the European Union (2001-2002) Asylum Applications- Who Decides?, $19^{\text {th }}$ Report, session 2001-02.

Labayle, H. (2011). Le Droit Européen de 'Asile devant ses Juges: précisions ou remise en question?. RFDA:273.

McDonough P. \& Tsourdi E. (2012a). The 'Other' Greek Crisis: Asylum and EU Solidarity'. Refugee Survey Quarterly, 31: 67-100.

McDonough P. \& Tsourdi L. (2012b). Putting Solidarity to the Test: Assessing Europe's Response to the Asylum Crisis in Greece, UNCHR, New Issues in Refugee Research, Research paper No. 231.

Mitsilegas V. (2012a). Immigration Control in an Era of Globalisation: Deflecting Foreigners, Weakening Citizens, Strengthening the State'. Indiana Journal of Global Legal Studies, 19: $3-60$.

Mitsilegas V. (2012b). The Limits of Mutual Trust in Europe's Area of Freedom, Security and Justice. From Automatic Inter-state Cooperation to the Slow Emergence of the Individual. Yearbook of European Law 2012, 31, pp. 319-372.

Mitsilegas, V. (2009). EU Criminal Law. Oxford/Portland, Oregon/Hart.

Mitsilegas, V. (2006). The Constitutional Implications of Mutual Recognition in Criminal Matters in the EU. Common Market Law Review, 43: 1277-1311.

Mitsilegas, V. (1998). Culture in the Evolution of European Law: Panacea in the Quest for Identity? in Fitzpatrick P. \& Bergeron J.H. (eds.) Europe's Other:European Law between Modernity and Postmodernity. Ashgate-Dartmouth, $p p$. 111-129.

Moreno-Lax, V. (2012). Dismantling the Dublin System: M.S.S. v. Belgium and Greece. European Journal of Migration and Law, 14: 1-31.

Nicolaidis, K. (2007). Trusting the Poles? Constructing Europe through Mutual Recognition. Journal of European Public Policy, 14:682-698.

Noll, G. (2003). Risky Games? A Theoretical Approach to Burden-Sharing in the Asylum Field. Journal of Refugee Studies, 16:236-252.

Ross, M. (2010). Solidarity: A New Constitutional Paradigm for the EU? in Ross M. \& BorgmannPrebil Y. (eds.) Promoting Solidarity in the European Union. Oxford University Press pp. 23-45.

Sangiovanni A. (2013). Solidarity in the European Union. Oxford Journal of Legal Studies, 33: 213-241.

Thielemann E. (2003a). Editorial Introduction. Journal of Refugee Studies, 16: 225-235

Thielemann E. (2003b). Between Interests and Norms: Explaining Burden-Sharing in the European Union. Journal of Refugee Studies, 16: 253-273.

\section{About the author}

Valsamis Mitsilegas is professor of European Criminal Law and Head of the Department of Law, Queen Mary University of London.

Email:v.mitsilegas@qmul.ac.uk 


\section{(c) (1) $(9)$}

BY NC ND 2014 Mitsilegas / Amsterdam University Press.

This is an Open Access article distributed under the terms of the Creative Commons Attribution License (http://creativecommons.org/licenses/by/2.0), which permits unrestricted use, distribution, and reproduction in any medium, provided the original work is properly cited. 